Jurnal Sulolipu : Media Komunikasi Sivitas Akademika dan Masyarakat

Vol. 19 No.12019

e-issn : 2622-6960, p-issn : 0854-624X

\title{
Analisis Kondisi Sanitasi Dengan Keberadaan Bakteri Coliform Pada Daging Sapi \\ Di Pasar Terong Kota Makassar \\ Wahyuni Sahani ${ }^{1}$ dan Indah Rahmana Nasir ${ }^{2}$ \\ unisahani@gmail.com \\ 1.2 Jurusan Kesehatan Lingkungan Politeknik Kesehatan Kemenkes Makassar
}

\begin{abstract}
Meat is a common source of pathogenic germs that can be transmitted to humans through a transfer pathway. Meat is an excellent medium for the growth of Coliform bacteria which is an indicator of sanitation. The purpose of this study was to determine the sanitary conditions with the presence of Coliform bacteria in beef in the City of Makassar Eggplant Market which includes conditions of the place of sale, equipment, and hygiene of traders. This type of research used observational research with a descriptive approach of 12 beef samples. The results showed that the value of the overall variable effort to condition beef sales is $100 \%$ in bad criteria. The value of the overall effort variable The condition of beef seller equipment is $58 \%$ in the bad criteria, and the hygiene condition of the cattle trader the value of the overall variable $50 \%$ is included in the bid criteria. And the presence of Coliform bacteria in beef from 12 beef samples and 1 sample of clean water which was examined with the results of bacterial contamination> 2400 colonies/gram that did not meet the requirements. If referred to by Indonesian National Standard No. 7338 of 2009, the results of the examination did not meet the requirements. It was concluded that the condition of market sanitation with the presence of Coliform bacteria in beef in Makassar City's Eggplant Market does not meet the requirements and supervision from the Health Office regarding the importance of hygiene and sanitation of traders related to the bacteriological quality of beef in Makassar City's Eggplant Market.
\end{abstract}

Keywords: Sanitation Conditions, Beef, Coliform Bacteria

\section{ABSTRAK}

Daging adalah sumber umum kuman patogen yang dapat ditularkan ke manusia melalui suatu jalur pemindahan.Dagingmerupakan media yang sangatbaikuntukpertumbuhanbakteriColiform yang merupakan indikator dalam sanitasi. Tujuan penelitian ini adalah untuk mengetahui kondisi sanitasi dengan keberadaan bakteri Coliform pada daging sapi di Pasar Terong Kota Makassar yang meliputi kondisi tempat penjualan, peralatan dan higiene pedagang.Jenis penelitian yang digunakan penelitian observasional dengan pendekatan deskriptif dari 12 sampel daging sapi Hasil penelitian menunjukkan bahwa nilai dari keseluruhan variabel upaya kondisi tempat penjualan daging sapi adalah $100 \%$ dalam kriteria buruk. Nilai dari keseluruhan variabel upaya Kondisi peralatan penjual daging sapi adalah $58 \%$ dalam $\mathrm{kriteria}$ buruk, dan kondisi higiene pedagang sapi nilai dari keseluruhan variabel $50 \%$ termasuk dalam kriteria buruk. Serta keberadaan bakteri Coliform pada daging sapi dari 12 sampel daging sapi dan 1 sampel air bersih yang diperiksa dengan hasil cemaran bakteri $>2400$ koloni/gram yang tidak memenuhi syarat. Apabila dirujuk dengan Standar Nasional Indonesia No. 7338 Tahun 2009, maka hasil pemeriksaan tidak memenuhi syarat. Disimpulkan bahwa kondisi sanitasi pasar dengan keberadaan bakteri Coliform pada daging sapi di Pasar Terong Kota Makassar tidak memenuhi syarat dan perlu dilakukan pengawasandari Dinas Kesehatan tentang pentingnya hygiene dan sanitasi pedagang terkait kualitas bakteriologis daging sapi di Pasar Terong Kota Makassar.

Kata Kunci :Kondisi Sanitasi, Daging Sapi, Bakteri Coliform

\section{PENDAHULUAN}

Sanitasi pasar merupakan sebagian beratap dan sebagian tidak beratap ditunjuk dengan keputusan DPRD dimana pedagang-pedagang berukumpul untuk memperdagangkan dan menjual barang-barang dagangan. Adapun yang harus diperhatikan dalam sanitasi pasar ialah : letak, gedung, fasilitas-fasilitas dan tempat penjualan. (Suparlan, 2012).

Menurut World Health Organization (WHO), makanan adalah semua substansi yang dibutuhkan oleh tubuh tidak termasuk air, obatobatan, dan substansi-substansi lain yang digunakan untuk pengobatan. Air tidak termasuk dalam makanan karena merupakan elemen hang vital bagi kehidupan manusia. (WHO, dalam Budiman, 2014). Makanan yang kita makan bukan saja harus sehat dan mempunyai bentuk yang menarik, aman dalam arti tidak mengandung mikroorganisme dan bahan kima yang dapat menyebabkan penyakit atau gangguan kesehatan akan tetapi harys pula higienes.

Daging adalah sumber umum kuman patogen yang dapat ditularkan ke manusia melalui suatu jalur pemindahan. Binatang yang disembelih dapat saja mengandung penyakit, atau memang sudah sakit, atau daging dapat tertular kuman patogen pada waktu penyembelihan, pengolah di rumah potong atau pengangkutan (Cecep, 2015). Daging merupakan sumber protein yang baikbagikesehatan. Daging segar jika tak 
Jurnal Sulolipu : Media Komunikasi Sivitas Akademika dan Masyarakat

Vol. 19 No.12019

e-issn : 2622-6960, p-issn : 0854-624X

ditangani dengan baik bisa tercemar bakteri yang berbahaya bagi kesehatan.

Daging merupakan media yang sangat baik untuk pertumbuhan bakteri Coliform.Jenis Enterobacter dengan Eschericia dan Klebsiella disebut kelompok bakteri Coliform yang merupakan indicator dalam sanitasi. Bakteri Coliform dalam jumlah tertentu dapat menjadi indicator suatu kondisi yang bahaya dan adanya kontaminasi bakteri patogen (Balia dkk, 2013).

Berdasarkan dari uraian-uraian diatas maka penulis tertarik melakukan penelitian mengenai "Analisis Kondisi Sanitasi Dengan Keberadaan Bakteri Coliform Pada Daging Sapi Di Pasar Terong Kota Makassar".

\section{BAHAN DAN METODE}

\section{Lokasi Penelitian:}

Lokasi penelitian dilakukan di Jalan Terong, Wajo Baru, Kecamatan Bontoala, Lokasinya diapit dua jalan protokol yakni, Jalan Urip Sumihardjo dan Jalan Masjid Rayayang memiliki luas tanah $16.368 \mathrm{~m}^{2}$ dan luas bangunan $27.000 \mathrm{~m}^{2}$.Sedangkan untuk pemeriksaan sampel dilakukan di Kampus Jurusan Kesehatan Lingkungan.

2. Desain dan Variabel Penelitian

Adapun jenis penelitian yang digunakan adalah penelitian observasional dengan pendekatan deskriptif, dimana variabel bebas dan variabel terikat dibandingkan secara bersamaan guna mengetahui hubungan anatara variabel variabel tersebut.

Adapun variabel penelitian pada penelitian ini terdiri dari 3 variabel. Yaitu variabel bebas yang terdiri dari tempat penjualan, peralatan, higiene pedagang, variabel terikat yaitu bakteri coliform pada daging sapi, serta variabel pengganggu yaitu air bersih dan proses pengangkutan.

\section{Populasi dan Sampel}

Adapun populasi dalam penelitian ini adalah semua penjual daging sapi yang berjumlah 60 penjual dari 6 los tempat penjual dan 54 hamparan di pasar terongKota Makassar.

Sampel dalam penelitian ini sebagian dari populasi yang berjumlah 12 sampel dimana dalam 1 los diambil 2 sampel menggunakan metode purposive sampling dengan pertimbangan dan kriteria tertentu yaitu: karena kondisi los dan

hamparan tempat penjualan relatif sama (homogen).

4. Pengumpulan data

Sumber data terdiri dari 2 yaitu data primer yang diambil secara langsung oleh peneliti dan data sekunder beberapa referensi baik artikel-artikel, jurnal, penelitian sebelumnya, buku maupun literatur yang lain yang dianggap dapat mendukung teori yang ada serta dianggap memiliki keterkaitan dengan penelitian.

Pengumpulan data dilakukan dengan menggunakan metode observasi dan pengambilan sampel daging sapi.

\section{Analisa Data}

Analisa data dilakukan dengan menggunakan tabel beserta pembahasannya dan disimpulkan dengan menggunakan menggunakan Skala guttman, Microsoft excel, dan Microsoft word.

\section{HASIL}

\section{Usia}

Tabel. 5.1

Distribusi Responden Berdasarkan Usia Penjual Daging Sapi Di Pasar Terong Kota Makassar

\begin{tabular}{|c|c|c|c|}
\hline NO. & USIA & JUMLAH & $\%$ \\
\hline 1. & $\begin{array}{l}17-26 \\
\text { tahun }\end{array}$ & 3 & 25 \\
\hline 2. & $\begin{array}{l}27-36 \\
\text { tahun }\end{array}$ & 4 & 34 \\
\hline 3. & $\begin{array}{l}37-46 \\
\text { tahun }\end{array}$ & 5 & 41 \\
\hline \multicolumn{2}{|c|}{ Jumlah } & 12 & 100 \\
\hline
\end{tabular}

\section{Jenis Kelamin}

Tabel. 5.2

Distribusi Responden Jenis Kelamin Penjual Daging Sapi Di Pasar Terong Kota Makassar NO. JENIS JUMLAH \% KELAMIN

\begin{tabular}{cccc}
\hline 1. & Perempuan & 0 & 0 \\
2. & Laki-Laki & 12 & 0 \\
\hline Jumlah & & $\mathbf{1 2}$ & $\mathbf{1 0 0}$ \\
\hline \multicolumn{2}{l}{ Sumber : Data Primer Mei 2018}
\end{tabular}


Jurnal Sulolipu : Media Komunikasi Sivitas Akademika dan Masyarakat

Vol. 19 No.12019

e-issn : 2622-6960, p-issn : 0854-624X

\section{Tingkat Pendidikan}

Tabel. 5.3

Distribusi Responden BerdasarkanTingkat Pendidikan Penjual Daging Sapi Di Pasar Terong Kota Makassar

\begin{tabular}{cccc}
\hline NO. & $\begin{array}{c}\text { TINGKAT } \\
\text { PENDIDIKAN }\end{array}$ & JUMLAH & $\%$ \\
\hline 1. & SD/MI & 1 & 9 \\
2. & SMP & 3 & 25 \\
3. & SMA/SMK/MA & 5 & 41 \\
4. & Perguruan & 3 & 25 \\
\multicolumn{4}{c}{ Tinggi } \\
Jumlah & $\mathbf{1 2}$ & $\mathbf{1 0 0}$ \\
\hline Sumber : Data Primer Mei 2018
\end{tabular}

4. Kondisi Tempat Penjualan

Tabel. 5.4

Hasil Observasi Kondisi Tempat Penjualan Daging Sapi Di Pasar Terong Kota Makassar

\begin{tabular}{cccc}
\hline NO. & KRITERIA & JUMLAH & $\%$ \\
\hline 1. & Baik & 0 & 0 \\
2. & Buruk & 12 & 100 \\
\hline & Jumlah & $\mathbf{1 2}$ & $\mathbf{1 0 0}$ \\
\hline
\end{tabular}

Sumber : Data Primer Mei 2018

\section{Kondisi Peralatan}

Tabel. 5.5

Hasil Observasi Kondisi Tempat Peralatan Daging Sapi Di Pasar Terong Kota Makassar

\begin{tabular}{|c|c|c|c|}
\hline NO. & KRITERIA & JUMLAH & $\%$ \\
\hline 1. & Baik & 5 & 42 \\
\hline 2. & Buruk & 7 & 158 \\
\hline & Jumlah & 12 & 100 \\
\hline
\end{tabular}

6. Kondisi Higiene Pedagang

Tabel. 5.6

Hasil Observasi Kondisi Tempat Peralatan Daging Sapi Di Pasar Terong Kota Makassar

\begin{tabular}{cccc}
\hline NO. & KRITERIA & JUMLAH & $\%$ \\
\hline 1. & Baik & 6 & 50 \\
2. & Buruk & 6 & 50 \\
\hline \multicolumn{2}{c}{ Jumlah } & $\mathbf{1 2}$ & $\mathbf{1 0 0}$ \\
\hline Sumber : Data Primer & Mei 2018
\end{tabular}

\section{Bakteri Coliform}

Tabel. 5.7

Hasil Pemeriksaan Bakteri Coliform Pada Daging Sapi dan Air Bersih Di Pasar Terong Kota Makassar

\begin{tabular}{cccccc}
\hline \multirow{2}{*}{ No. } & Kriteria & \multicolumn{2}{c}{ Daging } & \multicolumn{2}{c}{ Air Bersih } \\
\cline { 3 - 6 } & $\begin{array}{c}\text { Juml } \\
\text { ah }\end{array}$ & $\begin{array}{c}\text { Juml } \\
\text { ah }\end{array}$ & $\%$ \\
\hline 1. & $\begin{array}{c}\text { Tidak } \\
\text { Memenuhi } \\
\text { Syarat }\end{array}$ & 12 & 100 & 1 & 100 \\
\hline 2. & $\begin{array}{c}\text { Memenuhi } \\
\text { Syarat }\end{array}$ & 0 & 0 & 0 & 0 \\
\hline & Total & $\mathbf{1 2}$ & $\mathbf{1 0 0}$ & $\mathbf{1}$ & $\mathbf{1 0 0}$ \\
\hline
\end{tabular}

Sumber : Data Primer Mei 2018

\section{PEMBAHASAN}

1. Kondisi Tempat Penjualan

Aspek yang mempengaruhi sanitasi pasar yaitu, air bersih, tempat cuci tangan, pengolahan sampah, drainase, binatang penular penyakit atau vektor, kualitas makanan dan bahan pangan, dan desinfeksi pasar (Kepmenkes RI, 2008).

Berdasarkan hasil observasi yang dilakukan pada lokasi pasar terong kota makassar pada bulan mei 2018, pada kondisi tempat penjualan daging sapi pada 12 penjual termasuk dalam kriteria buruk menurut Kepmenkes RI, NO. 519/MENKES/SK/VI/2008 tentang Pedoman Penyelenggaran Pasar Sehat dengan persentase $100 \%$ kriteria berdasarkan lembar observasi.Hal ini disebabkan tempat penjualan berada pada sumber pencemaran terjadinya bakteri pada daging sapi yang terjual.

Kondisi los tempat penjualan daging sapi sumber air yang digunakan yaitu sumur bor. Berdasarkan hasil observasi yang telah dilakukan secara keseluruhan pada semua los tidak tersedia tempat cuci tangan, sehingga dari banyaknya los tempat penjual daging hanya beberapa los yang tersedia air yang mengalir tetapi tidak tersedia sabun untuk kebersihan higiene penjual setelah melakukan aktivitas menjual. Secara bakteriologis telah dilakukan pemeriksaan di laboratorium diperoleh hasil jumlah bakteri Coliform $>2400$ dalam jumlah 100 $\mathrm{ml}$ tidak sesuai dengan standar Permenkes No. 32 tahun 2017 yaitu untuk 
syarat bakteriologi MPN Coliform yaitu 50 dalam jumlah per $100 \mathrm{ml}$.

Tempat penjualan untuk penjual daging sapi menggunakan meja yang semua rata tinggi minimal $60 \mathrm{~cm}$ di atas lantai. Semua meja yang digunakan terbuat dari bahan yang tahan karat. Meja yang digunakan setiap penjual ada yang terbuat dari kayu dan sebagian dari tehel. Daging juga diletakkan di meja jualan sehingga bersentuhan langsung dengan meja yang kotor. Namun sangat di sayangkan proes penyiapan daging di pasar terong kurang memperhatikan aspek santasi dan higienis, karena daging-daging yang dipersiapkan untuk dijual oleh penjual disimpan dengan suhu ruangan yang lembab juga mengakibatkan bakteri mudah tumbuh dan menyebabkan kerusakan daging.

Faktor yang menyebabkan adanya mikroorganisme pada sampel daging sapi yaitu kondisi tempat penjualan, dimana berada disekitar lokasi yang dapat menjadi pencemar pada saat menjual daging sapi. Lokasi yang masih rawan bencana alam seperti banjir, setiap kali hujan deras, lantai dasar pada bangunan pasar terong akan tergenang air, genangan air juga dapat menjadi tempat perkembangbiakkan vektor penyakit. Kondisi tempat penjualan perlu diperhatikan keamanannya karena dapat menyebabkan kontaminasi terhadap daging. Meja yang terbuka dan tidak di tutup setelah digunakan sangat kotor sehingga vektor dan binatang pengganggu dengan mudah keluar masuk melalui got dan naik di atas meja penjualan daging. Hanya dengan air, penjual membersihkan meja tersebut dan daging disimpan begitu saja. Sehingga pihak pasar perlu untuk melakukan upaya dengan memperbaiki tempat penjualan daging sapi seperti membuat los atau hamparan dalam kondisi rapat dan tertata rapi, sehingga terhindar dari sumber pencemar antara tempat penyimpanan daging dan tempat penyimpanan peralatan agar dapat meminimalisir pencemaran yang ada melihat lokasi penjual daging sapi yang dekat dengan sumber pencemaran. Dengan demikian vektor, debu atau asap dari sumber pencemar lain dapat dihindari dengan modifikasi tempat penjualan daging sapi.

Banyaknya penjualan daging sapi dalam kriteria penilaian dari tempat penjualan hanya beberapa hamparan yang menggunakan alat karkas daging untuk di gantung. Karkas merupakan daging sapi yang bertulang. Karkas ini digantung dengan posisi terbalikseperti leher dibawah sedangkan kaki diatas. Dilihat dari kondisi pasar terutama kondisi penjualan daging sapi yang terlihat alat karkas daging yang digantung sangat banyak yang berkarat dan sangat kotor sehingga kurangnya kebersihan dalam memelihara alat karkas daging tersebut memudahkan vektor dan binatang lainnya yang menjadi faktor menurunnya kualitas daging yang digantung.

Faktor yang menyebabkan adanya mikroorganisme pada sampel daging sapi yaitu kondisi tempat penjualan dekat dengan sumber pencemaran yang tidak tersedia tempat sampah tertutup. Hanya tempat sampah yang terbuka dan tidak kedap air sehingga terdapat vektor penularan penyakit yaitu lalat yang dapat memungkinkan penularan penyakit seperti diare. Selain itu memudahkan lalat yang berasal dari tempat sampah maupun dari saluran limbah yang terbuka dan saluran limbah lainnya yang berasal dari limbah penjualan bahan pangan yang basah terlihat tergenang dan sangat kotor yang dekat dengan tempat penjualan tersebut memudahkan kecoa dan lalat hinggap terbang di permukaan daging.

Pada saat observasi terlihat kondisi tempat penjualan terdapat vektor dan binatang pengganggu dengan tempat perindukannya di sekelilling lokasi tempat penjualan tersebut mulai dari lalat, kecoa dan tikus karena pada los maupun hamparan penjual daging tidak menggunakan pintu yang dapat membuka dan menutup sendiri atau tirai plastik untuk menghalangi binatang penular penyakit yang dapat memungkinkan penularan penyakit.

Hasil observasi yang dilakukan oleh penulis sejalan dengan penelitian yang dilakukan oleh Jasmadi dkk (2014), menunjukkan bahwa hasil pemeriksaan jumlah bakteri Coliform pada sampel 
Jurnal Sulolipu : Media Komunikasi Sivitas Akademika dan Masyarakat

Vol. 19 No.12019

e-issn : 2622-6960, p-issn : 0854-624X

daging dari pasar tradisional pekanbaru menunjukkan dari 6 sampel yang diperiksa tidak ada yang memenuhi syarat berdasarkan Standar Nasional Indonesia (SNI) Nomor 7388:2009 yaitu $1 \times 10^{2}$ $\mathrm{MPN} / \mathrm{g}$. Hal tersebut dikarenakan oleh kondisi tempat penjualan yang masih kurang memperhatikan aspek kondisi sanitasi dan higienis pasar baik dari segi tempat penjualan bahan pangan, peralatan, higiene penjual serta suhu dan kelembaban yang mempengaruhi kualitas daging sapi sehingga perlu mendapat perhatian baik dari penjual itu sendiri maupun petugas terkait untuk meminimalisir tingkat cemaran mikroba. Hal ini sesuai dengan penelitian penulis, dimana tempat penjualan daging sapi, peralatan, dan higiene penjual penyebab tingginya jumlah cemaran bakteri Coliform pada daging sapi.

Penelitian tersebut selain dipengaruhi oleh sumber pencemaran dari tempat penjualan, hal ini juga dapat mempengaruhi padasaat proses pengangkutan.Dimana pada saat proses pengangkutan diduga daging sapi tersebut sebelumnya telah tercemar bakteri Coliform pada saat berada di Rumah Potong Hewan. sehingga daging yang dibawa ke pasar tersebut telah terkontaminasi bakteri Coliform yang sangat banyak dengan kondisi tempat penjualan yang tidak memenuhi kriteria baik berdasarkan hasil observasi.

\section{Kondisi Peralatan}

Kondisi pasar serta tata laksana pemasaran sangat berpengaruh terhadap timbulnya kontaminasi berbagai agen penyakit baik bakteri, virus, jamur maupun parasit.

Dalam penjualan maupun pengolahan makanan, peralatan yang digunakan harus memenuhi persyaratan agar aman dan tidak menimbulkan bahaya bagi kesehatan.

Sumber penularan penyakit dan penyebab terjadinya keracunan makanan yang tidak memenuhi syarat higiene peralatan. Peralatan yang tidak bersih dan mengandung mikroorganisme dapat menularkan penyakit melalui peralatan dalam proses pengolahan makanan. (Mundiatun dan Daryanto,2015).
Pada hasil observasi menunjukkan kondisi peralatan penjual daging dari 12 sampel penjual, 5 penjual termasuk dalam kriteria baik dengan persentase 42\%. 7 penjual termasuk dalam kriteria buruk dengan persentase $58 \%$ menurut Kepmenkes Rl, NO. 519/MENKES/SK/VI/2008 tentang pedoman penyelenggaran pasar sehat dengan persentase $50 \%$. Kriteria penilaian kondisi peralatan berdasarkan lembar observasi (terlampir).

Hal tersebut dapat disebabkan oleh beberapa faktor seperti proses pencucuian peralatan. Dari semua penjual daging sapi yang ada di pasar terong menggunakan alat pemotong talenan yang terbuat dari kayu yang kedap air. Talenan yang digunakan mudah dibershikan setelah menjual. Talenan yang digunakan dibersihkan dengan air yang tidak mengalir tanpa menggunakan sabun dan tidak dikeringkan dengan lap bersih. Hanya saja sebagian pedagang menggunakan talenen yang meja penjualannya terbuat dari tehel. Pedagang daging di pasar tersebut lebih memilih memotong daging langsung dimeja yang terbuat dari papan. Air yang digunakan hanya berasal dari air yang ditampung dalam ember untuk mencuci tangan dan peralatan seperti pisau, talenan dan meja penjualan dengan penggantian air bilasan yang sudah kotor. Pencucian peralatan yang digunakan harusnya dicuci dengan air yang mengalir yang cukup dan menggunakan sabun atau detergen.

Dilihat pada saat pengambilan sampel pada bulan mei, sebagian penjual daging memotong daging langsung di meja yang terbuat dari tehel maupun yang dari kayu. Hal ini menunjukkan bahwa peralatan pemotong daging yang seharusnya bersih telah tercemar bakteri. Adanya proses penyediaan daging di pasar terong ini yang kurang memperhatikan aspek sanitasi dan higiene sangat beresiko terjadi kontaminasi. Pengalas pemotong daging atau talenan tercemar akibat kurang kesadaran penjual untuk menjaga higienitas peralatan daging. Peralatan yang tidak dicuci sebelum berjualan hal tersebut dapat mengakibatkan bakteri dan kotoran yang menempel di talenan masih tertinggal, terlebih lagi beberapa penjual yang meninggalkan 
talenan yang digunakan di tempat jualan padahal tempat tersebut sanitasinya masih kurang baik sehingga sangat rentan terkontaminasi oleh bakteri.

Alat karkas daging yang digunakan terlihat sudah berkarat, kotor dan sangat tidak layak digunakan lagi. Daging yang digantung begitu saja terlihat dekat dengan tempat perindukkan vektor dan binatang pengganggu lainnya yang berasal dari atap plafon yang terbuka dengan kondisi bangunan yang lama. Akan tetapi sebagian penjual masih mereka gunakan seperti yang dijelaskan pada observasi kondisi tempat penjualan bahwa kurang nya kesadaran penjual untuk membersihkan setelah dipakai untuk mengganti karkas daging yang lainnya untuk digantung.

Pada alat pemotong seperti pisau yang digunakan semua penjual gunakan tidak berkarat. Beberapa penjual berulang kali mencuci tangan tanpa memperhatikan kebersihan air. Kebersihan pisau belum tentu dikatakan bersih karena hanya tidak berkarat, akan tetapi kontaminasi bakteri dalam air pada pisau yang digunakan saat dicuci menjadi faktor adanya cemaran bakteri karena saat pencucian peralatan tidak menggunakan sabun atau detergen. Hanya dengan air yang ditampung dalam wadah, penjual menucuci tangan dan mencuci pisau yang mereka gunakan dengan cara bersamaan bukan dengan air yang mengalir sehingga dapat mengakibatkan kontaminasi silang sehingga bakteri dapat berpindah kedalam daging sapi.

Dari banyaknya penjual daging sapi hanya beberapa penjual yang menggunakan alat pendingin untuk menyimpan daging yang yang belum laku terjual. Alat pendingin yang digunakan terlihat sudah lama, dilihat dari kondisi fisik lemari es sudah tidak layak digunakan karena kotor, bau dan berkarat. Kurangnya kesadaran penjual untuk membersihkan alat pendingin tersebut sehingga sangat mempengaruhi kondisi daging. Jika tidak ada fasilitas pendinginan, daging harus habis pada hari penyembelihan. Jika tidak memungkinkan habis pada hari yang sama, daging harus disajikan pada suhu dingin $\left(4^{\circ} \mathrm{C}\right)$ (PerkaBPOM, 2015).
Kriteria penilaian berdasarkan lembar observasi peralatan mudah dibersihkan, tetapi peralatan tidak dicuci menggunakan air yang mengalir dan sabun jika dikaitkan dengan hasil pemeriksaan laboratorium pada pemeriksaan bakteri Coliform pada daging sapi dan air bersih di pasar terong kota makassar, dari 12 penjual daging sapi di pasar terong 12 sampel daging sapi tidak memenuhi syarat dan 1 sampel air bersih tidak memenuhi syarat.

Hal tersebut tidak memenuhi syarat karena secara umum kebersihan peralatan kurang diperhatikan sehingga mempengaruhi kualitas bakteriologis daging sapi.

Hasil penelitian ini sejalan dengan penelitian sebelumnya yang dilakukan oleh Ahriani, Yuliana (2012), menunjukkan bahwa dari kedua belas sampel usap alat makan makanan lammang menunjukkan jumlah kuman yang melebihi dari standar berdasarkan Kepmenkes RI No. 715/Menkes/SK/V/2003 Tentang higiene sanitasi jasa boga (Peralatan makanan yaitu $100 \mathrm{koloni} / \mathrm{cm}^{2}$ ) hal ini disebabkan oleh beberapa faktor diantaranya pencucian air, penyimpanan peralatan disimpan dilemari yang tidak rapat serangga, tikus dan juga terkotaminasi dengan debu. Ini sesuai dengan penelitian penulis, dimana pencucian peralatan dan penyimpanan peralatan pada penjualan daging sapi menjadi penyebab tingginya jumlah cemaran mikroba pada daging tersebut.

\section{Kondisi Higiene Pedagang}

Higiene pada pedagang sangat berpengaruh terhadap keamanan pangan, agar bahan pangan tidak tercemar. Higiene penjual mempengaruhi kualitas makanan yang ditangai, higiene yang buruk dapat menyebabkan kontaminasi mikrobiologis pada makanan, karena penjamah makanan merupakan sumber utama dan potensial dalam kontaminasi makanan perpindahan mikroorganisme.

Higiene sebagai ilmu pengetahuan dasar mengenai kesehatan, haruslah memepertimbangkan keberadaaan lingkungan dimana manusia dan hewan tinggal satu kesatuan. Observasi lingkungan yang dimaksud. Kemudian diikuti penetapan sejumlah aturan-aturan yang sesuai sehingga dapat mempertahankan dan 
meningkatkan kesehatan umum serta dapat mencegah penyebaran penyakit.

Hasil observasi menunjukkan bahwa kondisi higiene pedagang daging sapi dari 12 sampel, 6 penjual termasuk dalam kriteria baik dengan persentase $50 \%$ dan 6 penjual termasuk dalam kriteria buruk dengan persentase $50 \%$. Pada 1 penjual dengan persentase $43 \%$ dan 5 penjual dengan persentase $29 \%$ menurut Kepmenkes Rl, NO. 519/MENKES/SK/VI/2008 tentang pedoman penyelenggaran pasar sehat dengan persentase $60 \%$. Kriteria penilaian kondisi higiene pedagang berdasarkan lembar observasi (terlampir).

Pada saat observasi dilakukan, usia produktif pedagang daging sapi yaitu usia 17-26 tahun sebanyak 3 orang (25\%), 27-36 tahun sebanyak 4 orang (34\%), 37-46 tahun sebanyak 5 orang (41\%). Sedangkan berdasarkan jenis kelamin $(100 \%)$ lebih didominasi oleh pedagang laki - laki yaitu sebanyak 12 orang. Menurut Yulia (2018) usia produktif dan jenis kelamin mempengaruhi kinerja seseorang. Kemampuan lebih mampu mencapai kinerja yang bagus. Jenis kelamin juga berhubungan dengan ketelitian, kebersihan, dan kerapian dalam bekerja. Perempuan cenderung lebih teliti dalam hal kebersihan dan kerapian sehingga dapat menerapkan atau melaksanakan higiene dan sanitasi dalam pengelolaan makanan dan bahan pangan.

Peroleh hasil yang tidak memenuhi syarat disebabkan oleh beberapa faktor diantaranya yaitu pedagang daging yang tidak memperhatikan kebersihan individu, dari hasil observasi yang telah dilakukan, pada umunya penjual daging tidak menjaga kebersihan tangan dari pengamatan yang dilakukan terlihat penggunaan celemek saat berjualan juga masih kurang baik karena beberapa penjual masih ada yang tidak menggunakan celemek. Bahkan ada yang tidak memakai baju saat menjual. Pedagang daging sapi ini juga menggunakan celemek sebagai lap tangan yang terlihat kotor, dan tidak mencuci celemek yang mereka gunakan untuk bekerja setiap hari. Hal tersbut sangat rentan terhadap kontaminasi silang pada bakteri, karena celemek yang kotor terlebih lagi yang tidak dicuci setiap harinya dapat menjadi sarang bakteri yang dapat berpindah ke dalam daging sapi yang diperjualbelikan.

Pedagang juga harus memakai sepatu yang memadai dan selalu dalam keadaan bersih. Dari semua pedagang daging sapi menggunakan sepatu boot pada saat bekerja. Dilihat dari kondisi sanitasi pasar yang kurang baik dilihat dari lantai pasar yang licin dan jalanan yang becek penggunaan sepatu boot dilakukan terutama untuk kebersihan individu mencegah terjadinya kutu air pada kaki.

Kontaminasi juga ditularkan melalui tangan, karena tangan bersentuhan langsung dengan bahan pangan. Dari semua pedagang daging sapi pada saat observasi, penjual tidak ada yang menggunakan sarung tangan saat menjual. Sudah menjadi kebiasaan para pedagang tidak menggunakan sarung tangan untuk memotong dan memegang daging saat menjual secara langsung sehingga kontaminasi dapat berasal dari tangan setelah memegang benda lain atau mencuci tangan dari pembilasan air peralatan yang sudah kotor sehingga bakteri dengan mudah menempel pada daging yang ingin dijual.

Dari keseluruhan penjual daging sapi yang menjadi sampel hanya ada beberapa penjual yang merokok pada saat menjual. Kebiasaan dan perilaku manusia yang ada di saat memasuki wilayah pasar dengan kondisi pasar yang sangat kotor dan bau sehingga penjual dan pembeli meludah sembarangan. Hal ini merupakan kebiasaan tidak sehat. Maka dari itu, disarankan kepada penjual dan pembeli menggunakan masker penututp mulut dalam menjual dan membeli daging agar dapat mengurangi kontaminasi yang ada di lingkungan pasar tersebut (Jasmadi, dkk. 2014).

Pencucian tangan merupakan salah satu faktor higiene yang ikut berpengaruh dengan terjadinya kontaminasi pada suatu makanan. Semua pedagang daging selalu mencuci tangan dengan air dan sabun setelah menjamah barang jualannya yaitu daging sapi. Tetapi saat pedagang selesai menjual daging, pendagang melakukan cuci tangan dengan air dan sabun di salah satu kamar mandi yang ada di pasar terong. Hal ini didasarkan karena masih ada pedagang yang mencuci tangan tidak memakai sabun 
Jurnal Sulolipu : Media Komunikasi Sivitas Akademika dan Masyarakat

Vol. 19 No.12019

e-issn : 2622-6960, p-issn : 0854-624X

ditempat penjualan daging sapi yang ada hanya tersedia air yang disimpan didalam ember pada saat berjualan.

Menurut Tamaroh dalam Rizsa (2015), faktor terpenting pada keamanan pangan adalah penjamah makanan. Penjamah makanan yang berpendidikan rendah akan melaksanakan tugasnya dengan mengandalkankebiasaan yang dimilikinya tanpa mengetahui alasan yang benar dalam melatarbelakangi tindakannya.

Berdasarkan hasil observasi yang telah dilakukan dapat diketahui bahwa jumlah pedagang yang berpendidikan SD sebanyak 1 orang (9\%), SMP/Mts sebanyak 3 orang (25\%), SMA/SMK/MA sebanyak 5 orang (41\%), Perguruan Tinggi sebanyak 3 orang (25\%). Hal ini menunjukan bahwa pengetahuan dan sikap yang baik tidak mendorong seseorang untuk berperilaku baik. Sehingga pada kenyataannya masih ditemukannya bakteri Coliform pada daging sapi yang disebabkan oleh higiene penjamah yang buruk.

Dari hasil observasi yang telah dilakukan, pada umumnya pedagang daging sapi masih ada yang tidak menjaga kebersihan tangan dari pengamatan yang dilakukan pada pedagang daging terlihat sebagian penjual berkuku panjang dan tidak terjaga kebersihannya. Kebersihan tangan terutama kuku, merupakan faktor yang sangat penting karena kuku dapat menjadi tempat perkembangbiakkan bakteri yang dapat menjadi media penularan bakteri pada saat menjual daging sapi. Hal ini disebabkan karena kurangnya pengetahuan dan kesadaran dibidang kesehatan untuk berperan aktif dalam mewujudkan derajat kesehatan masyarakat sehingga perilaku hidup bersih dan sehat tidak diterapkan pada pasar terong.

Hal ini sejalan dengan penelitian yang telah dilakukan Asmorowati dkk (2014) hubungan higiene pedagang dan sanitasi dengan kontaminasi Salmonella pada daging ayam potong di pasar Banjaran dan pasar Trayeman Kabupaten Tegal menunjukkan bahwa dua variabel yang ada hubungan dengan kontaminasi Salmonella pada daging ayam potong di pasar Banjaran dan pasar Trayeman Kabupaten Tegal yaitu higiene pedagang dan sanitasi pedagang daging ayam potong. Variabel yang paling dominan berpengaruh terhadap kontaminasi Salmonella adalah higiene pedagang daging ayam potong.

\section{Kualitas Bakteriologis Daging Sapi}

Hasil Pemeriksaan laboratorium bakteri Coliform pada daging sapi di pasar terong Kota Makassar dari 12 penjual daging sapi di pasar terong Kota Makassar semua tidak memenuhi syarat dengan jumlah $>2400$ koloni/gram. Hasil tersebut tidak memenuhi persyaratan menurut Standar Nasional Indonesia (SNI) NO.7388 Tahun 2009 tentang batas maksimum cemaran mikroba dalam pangan untuk bakteri Coliform adalah $1 \times 10^{2} \mathrm{koloni} / \mathrm{gram}$.

Berdasarkan hasil observasi yang dilakukan oleh penulis hal tersebut berhubungan dengan kondisi sanitasi pasar yang menjadi penyebab tingginya cemaran bakteri Coliform pada daging sapi. Tingginya cemaran bakteri Coliform pada daging sapi dipengaruhi dari tempat penjualan. Tempat penjualan yang berada dilantai dasar dalam basemant dengan kondisi lokasi yang kotor dengan jalanan yang becek karena banyaknya genangan air dan sampah sehingga menyebabkan adanya peluang vektor seperti lalat dapat bersarang dan mengontaminasi tempat penjualan.

Kondisi peralatan juga merupakan penyebab tingginya cemaran bakteri Coliform pada daging sapi. Kondisi peralatan juga dapat mempengaruhi kualitas bakteriologis. Sumber kontaminasi dalam penjualan yang menggunakan peralatan yang tidak dicuci dengan air bersih dan sabun, peralatan juga disimpan pada tempat terbuka hal ini yang menyebabkan bakteri Coliform pada daging sapi tersebut tinggi.

Higiene penjual juga merupakan faktor penyebab tingginya cemaran bakteri Coliform pada daging sapi tersebut. Penjamah daging sapi yang kurang mengetahui pentingnya hygiene dan sanitasi dalam menjual bahan pangan seperti daging sapi. Hasil observasi yang dilakukan penulis bahwa masih banyak penjual daging sapi yang kurang memperhatikan kebersihan perorangan, tidak memakai celemek, sarung tangan, masker, dalam berjualan selalu meludah sembarangan. Hal ini dapat memicu tingginya cemaran bakteri Coliform pada daging sapi (Arnia, 2013) 
Jurnal Sulolipu : Media Komunikasi Sivitas Akademika dan Masyarakat

Vol. 19 No.12019

e-issn : 2622-6960, p-issn : 0854-624X

Tinggi rendahnya cemaran bakteri Coliform yang terdapat pada daging sapi dihasilkan tidak memenuhi syarat disebabkan karena kondisi peralatan dan hygiene penjual mempengaruhi kualitas daging yang mereka jual ke konsumen terutama dalam segi bakteriologis yaitu banyaknya jumlah cemaran bakteri karena pada setiap langkah penjualan sangatlah mungkin menjadi sumber pencemaran bakteri pada daging sapi yang diperjualbelikan.

Selain dari pada kondisi peralatan dan higiene sanitasi penjual mempengaruhi daging sapi. Pada saat pengangkutan dari Rumah Potong Hewan pun sangat mempengaruhi kualitas daging tersebut karena pada saat proses pemotongan kemungkinan daging sudah tercemar bakteri Coliform yang dicampur dengan daging yang belum habis terjual setelah di simpan di lemari es untuk dijualkan kembali diatas meja tanpa menggunakan alas plastik. Variabel penggangu dalam penelitian ini juga terdapat pada saat proses pengangkutan juga yang menjadi kontaminasi selama dalam penyimpanan. Penyimpanan daging pada saat pengangkutan di ambil menggunakan keranjang yang terbuka dan daging dibungkus menggunakan kantong plastik yang tidak steril. Kontaminasi (sewaktu penyembelihan) dengan mikroba yang berasal dari kotoran, kulit, rambut, alat-alat penyembelihan, pekerja,air,udara, dan lingkungan tempat penyembelihan Sehingga mempengaruhi daging sapi apabila daging yang derajat kematangannya yang tidak baik akan mudah menimbulkan penyakit bila dikonsumsi oleh konsumen.

Pada penelitian yang dilakukan oleh Arnia dan Efrida (2013) tentang identifikasi kontaminasi bakteri Coliform pada daging sapi segar yang dijual di pasar sekitar kota Bandar Lampung, menunjukkan bahwa dari 14 sampel 1 diantaranya memenuhi syarat dan 13 tidak memenuhi syarat hal ini disebabkan oleh kondisi higiene dan sanitasi penjual daging sapi. Ini pun sejalan dengan penelitian yang dilakukan pada daging sapi di pasar terong Kota Makassar yang dari hasil observasi ditemukan bahwa kondisi higiene penjual yang mempengaruhi adanya cemaran mikroba pada daging tersebut.
Namun, dari penelitian yang dilakukan tidak dilakukan uji statistik yang lebih mendalam untuk mengetahui hubungan antar variabel yang mungkin sangat berkaitan dengan kualtitas bakteriologis pada daging sapi dikarenakan penelitian ini bersifat dekriptif yang hanya berdasarkan pada gambaran umum saja

\section{Kualitas Bakteriologis Air Bersih}

Hasil Pemeriksaan laboratorium bakteri Coliform pada air bersih di pasar terong Kota Makassar dari 12 penjual daging sapi di pasar terong Kota Makassar satu sampel air bersih yang diambil untukn dijadikan sampel yaitu tidak memenuhi syarat dengan jumlah $>2400$ koloni/gram dalam jumlah $100 \mathrm{ml}$. Hasil tersebut tidak memenuhi persyaratan menurut Standar Permenkes No. 32 tahun 2017 yaitu untuk syarat bakteriologi MPN Coliform yaitu 50 dalam jumlah per $100 \mathrm{ml}$.

Berdasarkan hasil observasi yang dilakukan, hal tersebut diketahui berhubungan dengan kondisi sanitasi pasar yang merupakan penyebab tingginya cemaran bakteri Coliform pada air bersih. Tingginya cemaran bakteri Coliform pada air bersih salah satu penyebabnya dari tempat penjualan. Menurut (Nugroho, 2016), meskipun jenis bakteri ini tidak menimbulkan penyakit tertentu secara langsung, akan tetapi keberadaannya di dalam sumber air bersih menunjukkan tingkat sanitasi yang rendah.

Sampel air yang dilakukan pemeriksaan merupakan sampel yang berasal dari sumur bor di salah satu milik pedagang yang dimana air tersebut digunakan. Air sumur bor tersebut dialirkan melalui kran yang ditampung dalam ember dengan kondisi ember yang belum diketahui kualitas kebersihannya. Selain itu, kondisi ember yang tidak tertutup dapat menjadi peluang kontaminasi bakteri. Air yang disalurkan melalui pipa ini sudah tercemar oleh bakteri akibat bangunan dan kondisi pasar yang sudah lama tidak terawat sehingga air sangat rentan tercemar dari sumber pencemaran lain. Dimana terlihat tidak tersedianya drainase juga mengakibatkan air limbah merembes dan mempersempit lahan tempat penjualan sehingga air yang dialirkan melalui pipa telah tercemar bakteri. 
Jurnal Sulolipu : Media Komunikasi Sivitas Akademika dan Masyarakat

Vol. 19 No.12019

e-issn : 2622-6960, p-issn : 0854-624X

Adanya jumlah atau kandungan bakteri yang terdapat pada sampel air sumur bor kemungkinan besar disebabkan oleh jarak antara sumur dengan jamban kurang dari 10 meter. Kondisi saluran pembuangan air limbah mampet dan kurang memadai.

Walaupun disini tidak adanya pengaruh jarak septic tank terhadap jumlah bakteri Coliform, tetapi ada kemungkinan semakin lama jumlah bakteri Coliform akan semakin bertambah jika terjadi kebocoran septic tank dan infiltrasi yang tinggi karena disebabkan oleh gaya gravitasi serta kapiler yang dapat mempengaruhi kecepatan , arah aliran, dan besaran air yang mengalir. Gaya gravitasi bersifat mengalirkan air secara tegak lurus ke atas, ke bawah dan ke arah horizontal sehingga mempengaruhi laju pencemaran bakteri. Oleh karena itu, diperlukan pengukuran bakteri Coliform secara berkala.

Hasil penelitian ini sejalan dengan penelitian sebelumnya yang dilakukan oleh Riri Novita Sunarti (2015), menunjukkan bahwa dari 12 sampel menunjukkan positif MPN Coliform air sumur gali di RT. V Kelurahan Padang Jati tidak memenuhi persyaratan sesuai dengan Keputusan Menteri Kesehatan Nomor : 907/MenKes/SK/VII/202 tentang persyaratan dalam air minum. Sehingga air minum yang berasal dari 12 sumur gali tersebut tidak layak untuk dikonsumsi oleh masyarakat karena mengandung Coliform sehingga mempunyai efek yang tidak baik untuk kesehatan. Tetapi sejalan dengan penelitian ini hal ini merupakan faktor yang dapat menambah cemaran bakteri pada daging. Pencemaran bakteri Coliform dapat muncul dalam kondisi lingkungan yang lembab dan terbuka. Kondisi pasar yang ramai dan dipadati masyarakat mengakibatkan pertukaran udara menjadi tidak sehat disekitar pasar. Kontaminasi bakteri dalam air mempengaruhi daging yang dijual mulai dari pencucian peralatan sebelum memotong daging, kebersihan meja untuk penyimpanan daging dan higiene penjual itu sendiri.

\section{PENUTUP}

\section{KESIMPULAN}

Berdasarkan hasil penelitian yang telah dilakukan, maka dapat ditarik kesimpulan sebagai berikut:

1. Kondisi tempat pedagang daging sapi termasuk dalam kriteria buruk terhadap keberadaan bakteri Coliform pada daging sapi yang tidak memenuhi syarat.

2. Kondisi peralatan pedagang daging sapi termasuk dalam kriteria buruk terhadap keberadaan bakteri Coliform pada daging sapi yang tidak memenuhi syarat.

3. Kondisi higiene pedagang sapi termasuk dalam kriteria buruk terhadap keberadaan bakteri Coliform pada daging sapi yang tidak memenuhi syarat.

\section{SARAN}

1. Kepada para pengelola pasar hendaknya memperhatikan kondisi fasilitas sanitasi pada los tempat penjualandan hamparan agar dapat meminimalisir pencemaran yang ada.

2. Bagi pedagang karkas daging menggunakan alat pelindung diri seuai dengan pekerjaannya (sepatu boot, sarung tangan, celemek, penutup rambut, dan lain-lain).

3. Perlu adanya pengawasan dari Dinas Kesehatan tentang pentingnya hygiene dan sanitasi pedagang terkait kualitas bakteriologis daging sapi di pasar terong Kota Makassar.

\section{DAFTAR PUSTAKA}

Ahriani Yuliana. 2012. Studi Pengolahan dan Kualitas Bakteriologis Makanan Khas Lammanang Di Kecamatan Bangkala Kabupaten Jeneponto. Makassar : Poltekkes Makassar Jurusan Kesehatan Lingkungan Makassar. (KTI tidak diterbitkan).

Anonim. 2013. Bahaya, dampak dan akibat infeksi bakteri E. Coli (Online) http://www.tipscaraterbaik.com/bahayagejaladampak-bakteri-e-coli-terhadapkesehatan.html (Diakses pada pada tanggal 28 Desember 2017). 
Jurnal Sulolipu : Media Komunikasi Sivitas Akademika dan Masyarakat

Vol. 19 No.12019

e-issn : 2622-6960, p-issn : 0854-624X

Arnia dan Efrida. 2013. Identifikasi Kontaminasi Bakteri Coliform Pada Daging Sapi Segar yang Dijual di Pasar Sekitar Kota Bandar Lampung. Jurnal Kesehatan Universitas Lampung ISSN 2337-3776 : Hal 43-50. http://juke.kedokteran.unila.ac.id/index.php/majority/article/view/39 (Diakses pada tanggal 3 Desember 2017).

Asmorowati, dkk. 2014. Hubungan Higiene Pedagang dan Sanitasi Dengan Kontaminasi Salomenella Pada Daging Ayam Potong. (Online). https://journal. Unnes.ac.id/artikel_sju/ujph/3900 (Diakses 15 Juni 2018)

Badan Pusat Statistik Kota Makassar. 2016. Infalasi Kota Makassar. Sektor Perdagangan Pasar. Makassar : Pemerintah Kota Makassar.

Badan Pusat Statistik Kota Makassar. 2017. Provinsi Sulawesi Selatan Dalam Angka Sulawesi Selatan Provinsi in figure. Makassar.

Balia, dkk. 2013. Deteksi Coliform Pada Daging Sapi Giling Spesial yang Dijual di Hipermarket Bandung (Online).Pustaka.unpad.ac.id. (Diakses24 Desember 2017).

Budiman Chandra. 2014. Pengantar Kesehatan Lingkungan. Jakarta : Buku Kedokteran EGC.

Efri Malisa Dwi Putri. 2015. Hubungan Hygiene Sanitasi Dengan Kontaminasi Coliform Pada Air Minum Isi Ulang Di Kecamatan Seberang Ulu 1 Kota Palembang Tahun 2015. (Online) http://www.repository.uinjkt.ac.id/dspace/handle/123456789/2889 (Di akses pada tanggal 19 Desember 2017).

Erlani, dkk. 2011. Sanitasi Tempat-Tempat Umum dan Pariwisata. Makassar : Politeknik Kesehatan Makassar Jurusan Kesehatan Lingkungan.

Erni Nurkhayani, STP, MSE. 2015.Pengawasan Kemanan Pangan Segar. Jakarta Selatan:Kemenkes RI 2015

Hendraaty, H K. 2013. Pengemasan dan Penyimpanan Bahan Pangan. Yogyakarta : Graha Ilmu.

Henny Krissetiana Hendrastu. 2013. Pengemasan dan Penyimpanan Bahan Pangan. Yogkarta : Graha IImu

Jasmadi, dkk. 2014. Pravalensi Bakteri Coliform dan Escherichia coli Pada Daging Sapi yang di Jual di Pasar Tradisional dan Pasar Modern Kota Pekanbaru. JOM FMIPA Volume 1 No. 2. Hal 31-39. (Online).https://media.neliti.com/media/publications/183549-ID-prevalensibakteri-coliform-dan-escheric.pdf (Diakses pada tanggal 6 Desember 2017).

Javaurora, 2011. Bakteri Coliform. (Online) https://erickbio.wordpress.com/2011/07/03/baktericoliform/ (Diakses pada tanggal 28 Desember 2017).

Koes Irianto. 2013. Mikrobiologi Medis. Bandung : Alfabeta.

Mundiatun dan Daryanto. 2015. Pengelolaan Kesehatan Lingkungan. Yogyakarta : Gava Media.

Natalia, L.A. Bintari, S.H, dan Mustikaningtyas, D. (2014). Kajian Kualitas Bakteriologi Air Minum Isi Ulang Di kabupaten Blora. Unnes Journal of Live Science. Vol.3. No. 1, 32-34. (Online). https://journal.unnes.ac.id/artikel_sju/UnnesJLifeSci/2980 (Diakses pada tanggal 10 Januari 2018).

Nugroho Tristyanto. 2016. Uji Bakteriologi MPN Coliform dan Eschericia Coli pada Air Baku Kolam Renang di Kota Malang. Malang : PT. Semesta Anugerah. 
Jurnal Sulolipu : Media Komunikasi Sivitas Akademika dan Masyarakat

Vol. 19 No.12019

e-issn : 2622-6960, p-issn : 0854-624X

Nurul Amaliyah. 2017. Penyehatan Makanan dan Minuman - A. Yogyakarta : CV Budi Utama.

Nurwantoro, Ir dan Djarijah A S. 1997.Mikrobiologi Pangan Hewani-nabati. Yogyakarta: Kanisius.

Republik Indonesia. 2008. Keputusan Menteri Kesehatan Republik Indonesia Nomor : 519/MENKES/SK/VI/2008. Pedoman Penyelenggaraan Pasar Sehat.

Republik Indonesia. 2017. Peraturan Menteri Kesehatan Republik Indonesia No. 32 Tahun 2017 Tentang Standar Baku Mutu Kesehatan Lingkungan dan Persyaratan Kesehatan Air Untuk Keperluan Higiene Sanitasi, Kolam Renang, Solus Per Aqua, dan Permandian Umum.

Riri Novita Sunarti. 2015. Uji Kualitas Air Sumur Dengan Menggunakan Metode MPN (Most Probable Numbers).

Rizsa Puspita. 2015. Upaya Penjamah Makanan Dalam Menjaga Kualitas Ditinjau Dari Aspek Food Safety. Yogyakarta : Gava Media.

Rohanta, dkk. 2016. Gizi Kuliner Dasar. Jakarta : Buku Kedokteran EGC.

Siti Surasri. 1985. Prinsrip Sanitasi Makanan. Surabaya : Proyek Pengembangan Pendidikan Tenaga Sanitasi Pusat.

Sri Rejeki. 2015. Sanitasi Hygiene dan K3. Bandung : Rekayasa Sains.

Standar Nasional Indonesia. 2009. Badan Standarisasi Nasional. Nomor : 7388:2009. Batas Maksimum Cemaran Mikroba Dalam Pangan.

Sucipto D.C. 2015. Keamanan Pangan. Yogyakarta : Gosyen Publishing.

Supandi T dan Wardah. 2014. Mikrobiologi Pangan. Yogyakarta: CV ANDI

Suparlan. 2012. Pengantar Pengawasan Hygiene Sanitasi Tempat-Tempat Umum, Wisata danUsaha-Usaha Untuk Umum. Surabaya : Percetakan DuaTujuh.

Suriawiria. 1996. Mikrobiologi Air dan Dasar-Dasar Pengolahan Air Secara Biologis. Bandung : Alumni.

Winiati dan Nurwitri. 2012. Mikrobiologi Pangan. Bogor : IPB Press

Yulia. 2016. Higiene Sanitasi Makanan, Minuman Dan Sarana Sanitasi Terhadap Angka Kuman Peralatan Makan Dan Minum Pada Kantin. Jurnal Vokasi Kesehatan. 2 (1): 56. (online). http://ejournal.poltekkes-pontianak.ac.id. Diakses 20 November 2017. 